\title{
CLOSURE RATE OF A 700 m DEEP BORE HOLE AT MIZUHO STATION, EAST ANTARCTICA
}

\author{
by \\ Renji Naruse \\ (Institute of Low Temperature Science, Hokkaido University, Nishi 8, Kita 19, Sapporo 060, Japan) \\ Fumio Okuhira \\ (Gifu Prefectural Research Institute for Environmental Pollution, 58-2, Yabuta 8-chome, Gifu 500, \\ Japan) \\ Hirokazu Ohmae \\ (Institute of Low Temperature Science, Hokkaido University, Nishi 8, Kita 19, Sapporo 060, Japan) \\ Kunio Kawada \\ (Faculty of Science, Toyama University, Toyama 930, Japan) \\ and \\ Masayoshi Nakawo \\ (Department of Applied Physics, Faculty of Engineering, Hokkaido University, Sapporo 060, Japan)
}

\section{ABSTRACT}

Measurements of the bore-hole diameter were made with three-contact-point calipers from the shallow layer to a depth of $700 \mathrm{~m}$ at Mizuho Station, East Antarctica, in 1984-86. The minimum strain-rate (i.e. secondary creep rate) of the bore-hole closure was estimated from the observed creep curve at each depth. A relation between stress and strain-rate was deduced for a temperature of $-35^{\circ} \mathrm{C}$ and a stress range from 0.8 to $1.65 \mathrm{MN} \mathrm{m}^{-2}$, as

$$
\dot{\varepsilon}=6.49 \times 10^{-9} \tau^{2.87}
$$

where $\dot{\varepsilon}$ is the effective strain-rate $\left(\mathrm{s}^{-1}\right)$ and $\tau$ is the effective shear stress $\left(\mathrm{MN} \mathrm{m}^{-2}\right)$. This result shows that, for comparable overburden stresses and temperature, the bore-hole closure rates at Mizuho Station are higher than those measured in bore holes at Byrd Station and in the Northern Hemisphere ice caps (Paterson 1977).

\section{INTRODUCTION}

The closure rates of bore holes give useful information on the dynamics of glaciers and ice sheets. Extensive studies on bore-hole closure have recently been carried out with reference to some of the properties of ice, e.g. crystal fabrics at Cape Folger, East Antarctica (Thwaites and others 1984), dust content at Dye 3 in south Greenland (Gundestrup and Hansen 1984), and microparticle concentrations, grain-size, and other parameters at Agassiz Ice Cap in Ellesmere Island (Fisher and Koerner 1986).

Provided that the strain-rates are obtained from frequent measurements of bore-hole diameters over a wide range of depth, a stress-strain-rate relation can be deduced. Only a few studies have been done in this area: Nye (1953) analysed the Jungfraufirn bore hole, and Gow (1963) studied the Byrd Station bore hole. Paterson (1977) derived a power law for ice creep based on the data from Byrd Station, Site 2 in Greenland, and Meighan and Devon Island ice caps. However, Paterson's successful analysis was restricted to the low-stress range from 0.15 to $0.8 \mathrm{MN} \mathrm{m}^{-2}$, due to the difficulty of distinguishing the secondary (steady) creep stage in deep layers.

An ice-core drilling project was conducted in 1983-84 at Mizuho Station $\left(70^{\circ} 42^{\prime} 03^{\prime \prime S}, 44^{\circ} 17^{\prime} 36^{\prime \prime} \mathrm{E} ; 2247 \mathrm{~m}\right.$ a.s.1.), East Antarctica, by the 24th and 25th Japanese Antarctic Research Expeditions (JARE-24 and JARE-25). A $411 \mathrm{~m}$ deep bore hole was drilled in the austral winter of 1983 by JARE-24. A preliminary study of the bore-hole closure was made by Kawada and others (1986). JARE-25 drilled a new bore hole from 140 to $700.63 \mathrm{~m}$ depth during the period 2 June -1 August 1984. A thermal drill $168 \mathrm{~mm}$ in diameter was used down to a depth of $626 \mathrm{~m}$, and one $138 \mathrm{~mm}$ in diameter was used for the deeper part. The bore hole was not filled with liquid during or after drilling.

By analysing the results of measurements of closure rates in this bore hole, we can present a power law for ice creep in a relatively high stress range, from 0.8 to 1.65 $\mathrm{MN} \mathrm{m}{ }^{-2}$, at a temperature of $-35^{\circ} \mathrm{C}$.

\section{INSTRUMENTS AND METHODS}

The diameter gauge used for the Mizuho bore hole was a tandem one developed by the Institute of Low Temperature Science, Hokkaido University. Figure 1 is a schematic illustration of the gauge (Naruse and others 1985). It has two separate calipers $0.53 \mathrm{~m}$ apart, each having three contacting steel wheels (W) which are pressed against the wall of the bore hole by a spring (S). Two bars (F) are a device for releasing the gauge when it is stuck. Because of the use of two calipers in tandem, the gauge has such advantages as better alignment with the axis of the bore hole, and back-up in case one of the calipers malfunctions. The potentiometer of one of the calipers did not work well and only the other calipers were used. Change in diameter is converted into change in the output voltage by a rotational potentiometer (P) mounted on the axle of each of the calipers. The total length of the gauge is $1.4 \mathrm{~m}$, the power supply is $12 \mathrm{~V}$ d.c., and the range of measurement is 90-190 mm.

Another gauge was used for the narrow bore hole - a Geologger 300 manufactured by the Oyo Corporation, Japan. 


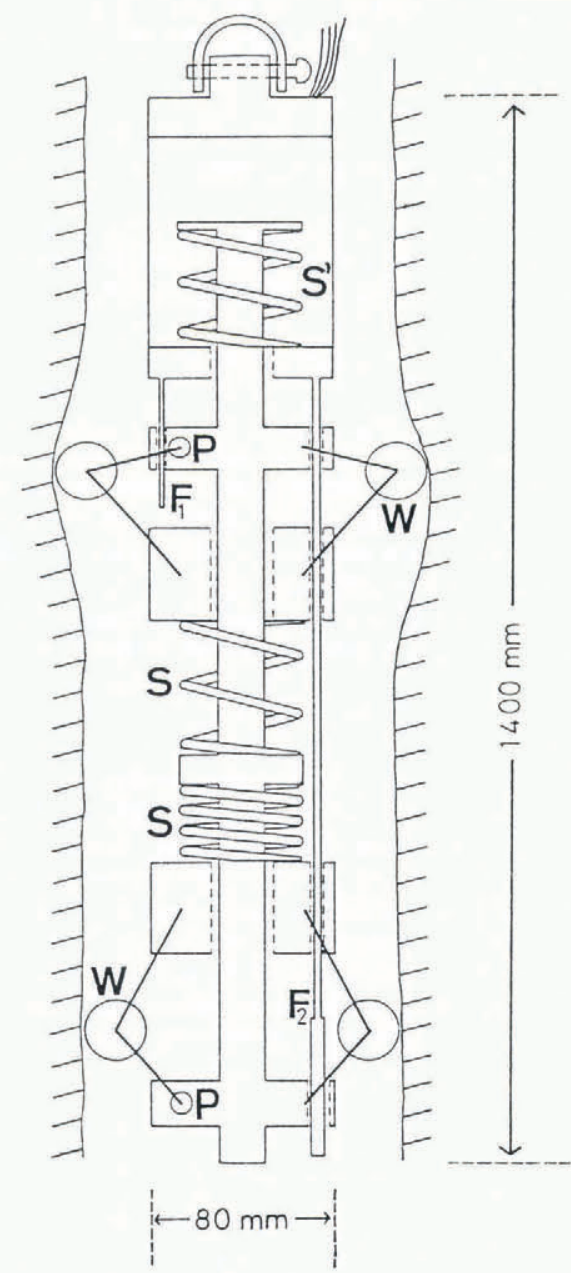

Fig. 1. Schematic illustration of a diameter gauge with two calipers in tandem. S: compressive spring; W: wheel; P : rotational potentiometer; F : rod for release.

Its caliper probe (model 3973) has two arms which are pressed against the wall of the bore hole by a spring. The gauge measures diameters from 65 to $100 \mathrm{~mm}$.

Calibrations were made before and after every measurement at Mizuho Station by using six plastic pipes whose diameters ranged from 67 to $158 \mathrm{~mm}$. Judging from these results, the accuracy of the gauges is about $\pm 1 \mathrm{~mm}$ for the tandem gauge and $\pm 2 \mathrm{~mm}$ for the Geologger calipers, provided the tips of the calipers are in good contact with the wall of the bore hole.

A power supply and recorder were placed outside the bore hole. Measurements were carried out continuously with depth, and the running speed of the gauge in the bore hole ranged from 0.2 to $0.25 \mathrm{~m} / \mathrm{s}$. Diameter at depth was obtained by averaging data measured while the gauge moved both downward and upward. The depth in the bore hole was determined by reading the length of winch cable released.

A profile of the bore-hole diameter was first measured to a depth of $700 \mathrm{~m}$ on 3 August 1984, $2 \mathrm{~d}$ after the completion of drilling. This survey was made with calipers which also had three contact points. Then, over a period of 2 years, measurements were carried out on a total of ten occasions. For diameters less than about $95 \mathrm{~mm}$, the Geologger calipers were used.

The temperature of ice in the bore hole was also measured, with a thermistor thermometer whose sensor was pressed against the wall of the bore hole by a spring. The resolution of the thermometer was $0.01{ }^{\circ} \mathrm{C}$.

\section{RESULTS OF THE SURVEY}

From the continuous records of diameter with depth, a mean diameter over $2 \mathrm{~m}$ depth intervals was estimated every

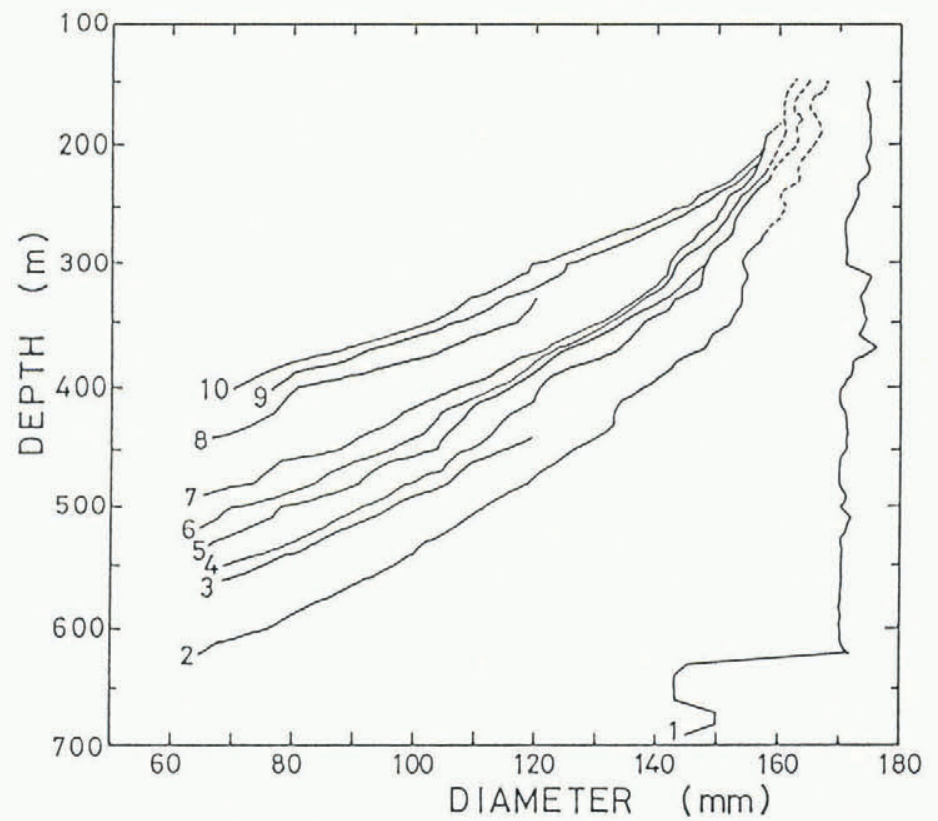

Fig. 2. Vertical distribution of the diameter in a $700 \mathrm{~m}$ deep bore hole at Mizuho Station. Numbers from 1 to 10 indicate the date of measurement: 1: 3 August 1984; 2 : 23 February 1985; 3: 30 April 1985; 4: 6 June 1985; 5: 1 July 1985; 6: 2 August 1985; 7: 12 September 1985; 8: 17 January 1986; 9: 9 May 1986; and 10: 7 July 1986.

$10 \mathrm{~m}$ (Okuhira and others 1987). Ten profiles of the bore-hole diameter are shown in Figure 2. It is noted that the diameter measurements fluctuate considerably: the widening of the diameter is the result of melting by the thermal drill. Observed diameters larger than $158 \mathrm{~mm}$ in the shallow layer were eliminated here, with the exception of data from the first survey, because of possible instrumental error in the large-diameter range. Due to the intensive contraction of the bore hole in the deep layer, measurements could only be made down to about $400 \mathrm{~m}$ depth in 1986. Based on the results of test drillings with the same types of thermal drill, the initial diameter of the bore hole is assumed to be $175 \mathrm{~mm}$ in the layer from 150 to $300 \mathrm{~m}$ depth, and to be $180 \mathrm{~mm}$ from 300 to $625 \mathrm{~m}$ depth. These values are used for calculations of strain.

Ice temperatures measured on 27-31 March 1985 (Okuhira, unpublished report) are listed in Table I for the layer from 280 to $540 \mathrm{~m}$ depth, and a stress-strain relation is analysed. Almost uniform temperature, from $-35.2^{\circ}$ to $-35.5^{\circ} \mathrm{C}$, is noted.

TABLE I. DATA OBTAINED FROM THE MIZUHO STATION BORE HOLE

$\begin{array}{ccccc}\text { Depth } y & \begin{array}{c}\text { Overburden } \\ \text { pressure } P \\ \left(\mathrm{MN} \mathrm{m}^{-2}\right)\end{array} & \begin{array}{c}\text { Effective shear } \\ \text { stress } \tau \\ \left(\mathrm{MN} \mathrm{m}^{-2}\right)\end{array} & \begin{array}{c}\text { Minimum } \\ \text { strain-rate } \dot{\varepsilon} \\ \left(\mathrm{s}^{-1}\right)\end{array} & \text { Temperature } \\ (\mathrm{m}) & & & & { }^{\circ} \mathrm{C} \\ 280 & 2.39 & 0.83 & 3.94 \times 10^{-9} & -35.4 \\ 300 & 2.57 & 0.90 & 4.63 & -35.4 \\ 320 & 2.75 & 0.96 & 5.56 & -35.5 \\ 340 & 2.93 & 1.02 & 6.48 & -35.5 \\ 360 & 3.11 & 1.08 & 8.56 & -35.5 \\ 380 & 3.29 & 1.15 & 1.02 \times 10^{-8} & -35.5 \\ 400 & 3.47 & 1.21 & 1.13 & -35.5 \\ 420 & 3.65 & 1.27 & 1.27 & -35.4 \\ 440 & 3.83 & 1.33 & 1.56 & -35.4 \\ 460 & 4.01 & 1.40 & 1.62 & -35.4 \\ 480 & 4.19 & 1.46 & 2.01 & -35.3 \\ 500 & 4.37 & 1.52 & 2.15 & -35.3 \\ 520 & 4.55 & 1.59 & 2.31 & -35.3 \\ 540 & 4.73 & 1.65 & 2.78 & -35.2\end{array}$




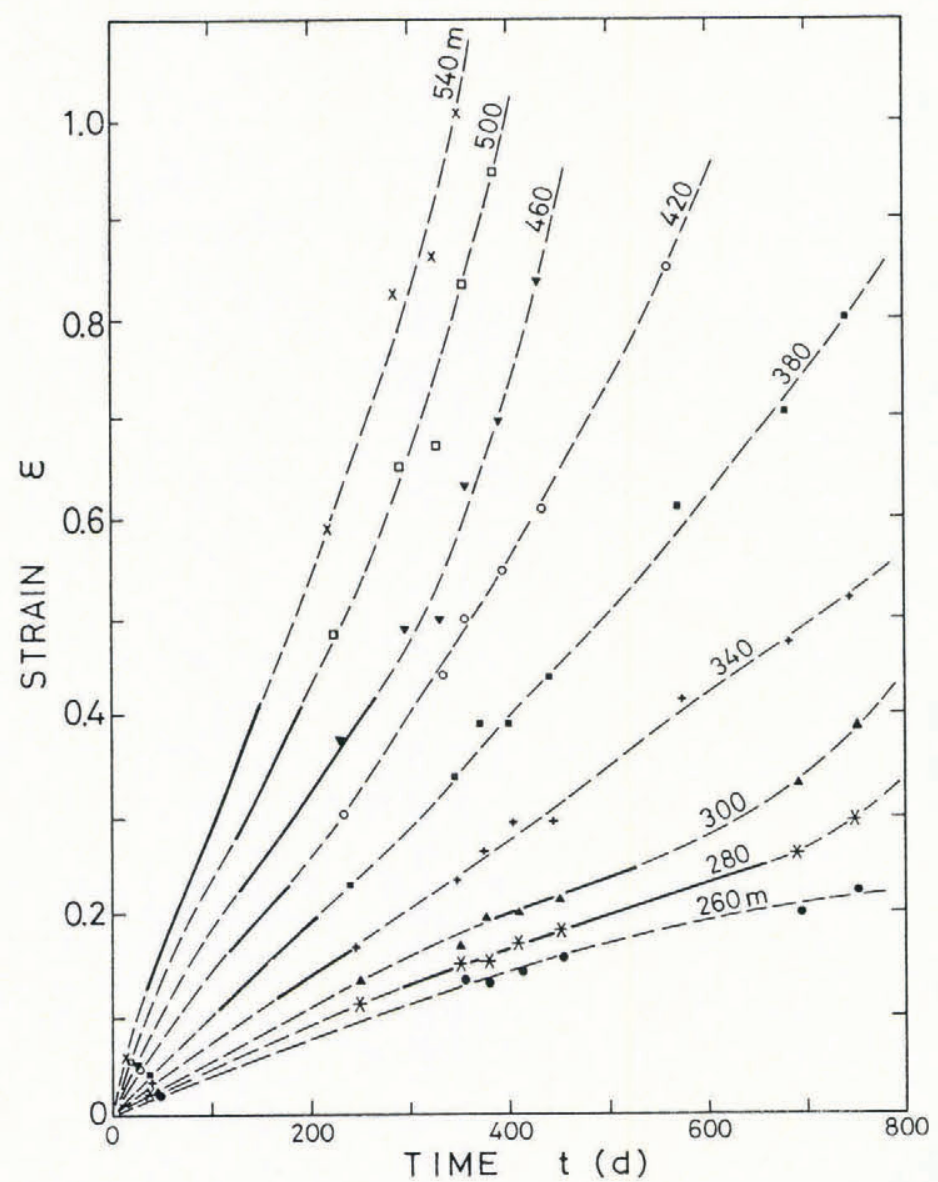

Fig. 3. Strain $\varepsilon$ versus time $t$ after drilling, shown at every $40 \mathrm{~m}$ depth. On 3 August 1984, when the first measurement was made, $t=49 \mathrm{~d}$ at $260 \mathrm{~m}$ depth, and $t=16 \mathrm{~d}$ at $540 \mathrm{~m}$ depth. Thick segments in the broken lines represent the ranges of $\varepsilon$ and $t$ used to estimate the minimum strain-rates.

\section{SECONDARY (MINIMUM) CREEP RATE}

Although the creep rate of ice is not homogeneous around a bore hole, i.e. the strain-rate is maximum at the wall of the bore hole and decreases with distance from the bore hole, Paterson (1977) showed that an appropriate measure of the strain $\varepsilon$ for the closure of a cylindrical hole was

$$
\varepsilon=-\ln \left(a / a_{0}\right)
$$

where $a_{0}$ is the initial diameter of the hole and $a$ is the diameter at the time of measurement.

Using the depth profiles of the diameter shown in Figure 2, a creep curve can be obtained at each depth where many measurements were made. Figure 3 shows the total strain $\varepsilon$ plotted against the time $t$ after drilling for every $40 \mathrm{~m}$ depth. Some deviations from smoothed curves are noted (shown by broken lines); they are considered to be caused either by accidental loose contacts of the calipers with the bore hole or by the decrease in sensitivity of the instrument at such a low temperature.

As mentioned by Gow (1963), Paterson (1977), and other investigators, secondary (steady) creep of ten cannot be recognized clearly in the deformation of a bore hole, but tertiary (accelerating) creep appears just after transient (decelerating) creep. It is also considered that tertiary creep, due to recrystallization of ice, starts in the deep layer when the ice in the shallow layer is still in a state of transient creep. Therefore we determine the minimum creep rate $\dot{\varepsilon}$, which may correspond to the secondary creep rate, from the slope $\mathrm{d} \varepsilon / \mathrm{d} t$ on the smoothed curve in Figure 3. The ranges of $\varepsilon$ and $t$, which were used to estimate the minimum creep rates, are indicated by thick lines in Figure 3. At a depth of $260 \mathrm{~m}$ the curve was regarded as transient creep.
Data for the minimum strain-rate were obtained at successive intervals of $10 \mathrm{~m}$ from 280 to $540 \mathrm{~m}$ depth and are listed in Table $\mathrm{I}$.

\section{STRESS - STRAIN-RATE RELATION}

If the ice is assumed to be isotropic and incompressible, the relation between the effective strain-rate $\dot{\varepsilon}$ and the effective shear stress $\tau$ is generally expressed as

$$
\dot{\varepsilon}=A \exp (-Q / R T) \tau^{n}
$$

where $Q$ is the activation energy for the creep of ice, $R$ is the gas constant, $T$ is the temperature of ice, and $A$ is a parameter which may depend on impurities (soluble and insoluble), crystal size, and other parameters as yet unstudied. Then, according to the plastic theory, the effective shear stress at the wall of a cylindrical hole submerged in pressure $P$, as shown by Nye (1953) and used by Paterson (1977) and other workers, can be given as

$$
\tau=-P / n
$$

If the bore hole is filled with liquid, $P$ is the net hydrostatic pressure between ice and liquid. In the present study, $P$ was calculated (Table I) by the density profile which was obtained from in-situ measurements of ice cores at Mizuho Station (Nakawo and Narita 1985; Fujii and others, unpublished report). From the relation between $\dot{\varepsilon}$ and $P$ (i.e. Equations (2) and (3)), and the data in Table I, $n$ was calculated by regression to have the value 2.87 . Then the values of $\tau$ were calculated and are also shown in Table I.

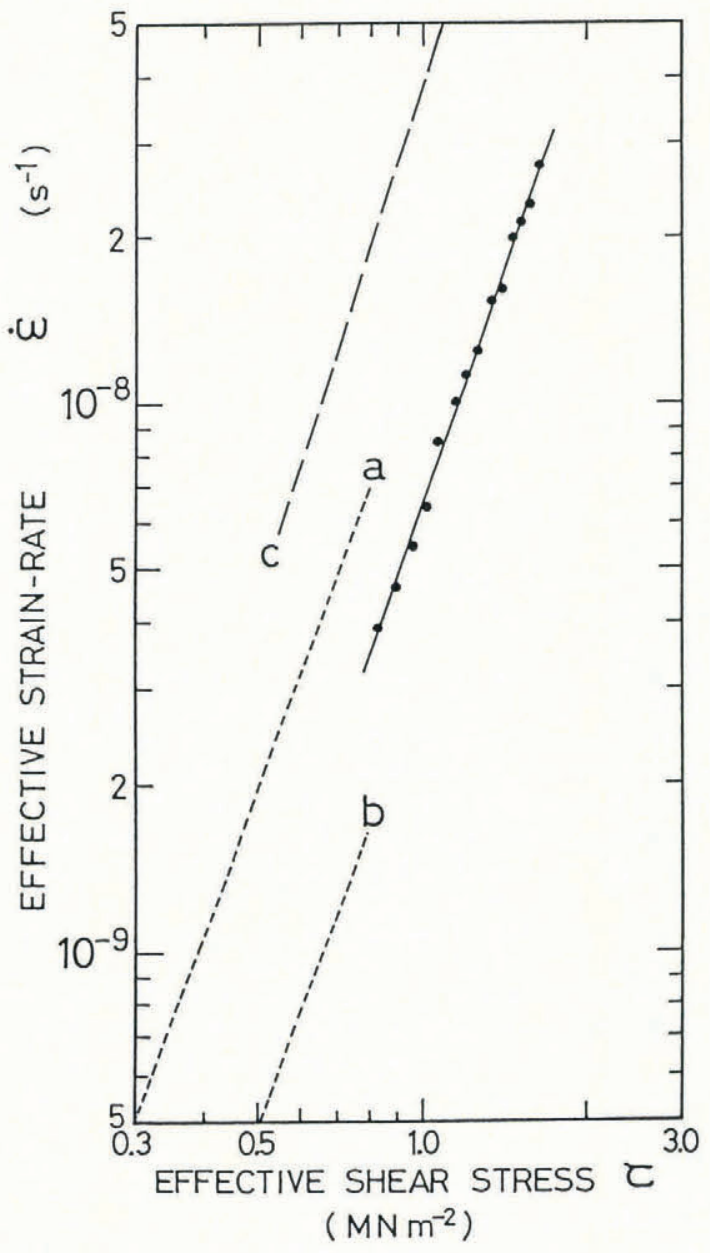

Fig. 4. Relation between the effective strain-rate $\dot{\varepsilon}$ and the effective shear stress $\tau$, plotted at every $20 \mathrm{~m}$ interval between 280 and $540 \mathrm{~m}$ depth. a: Paterson's (1977) relation at $-22^{\circ} \mathrm{C} ; \mathrm{b}$ : Paterson's relation adjusted to $-35^{\circ} \mathrm{C}$; c: Barnes and others' (1971) relation adjusted to $-35^{\circ} \mathrm{C}$. 
Figure 4 shows the relation between $\dot{\varepsilon}$ and $\tau$, which can be expressed as

$$
\dot{\varepsilon}=6.49 \times 10^{-9} \tau^{2.87}
$$

where $\dot{\varepsilon}$ is measured in $\mathrm{s}^{-1}$ and $\tau$ in $\mathrm{MN} \mathrm{m}^{-2}$. Also illustrated (by dotted lines) are Paterson's result at $-22^{\circ} \mathrm{C}$ and the same result adjusted to $-35^{\circ} \mathrm{C}$ by using his mean $Q$ value of $54 \mathrm{~kJ} \mathrm{~mol}^{-1}$. Although the range of effective stress is different for these two studies, Equation (4) indicates strain-rates approximately twice those of Paterson at the same temperature and stress. Fisher and Koerner (1986) concluded that the closure strain-rates in Holocene ice fit the Paterson line, but the rates in late Wisconsin ice show nearly three times the Holocene value in Agassiz Ice Cap. The detailed mechanism and reasons for this difference have not been made clear to date.

Strictly, we cannot compare the results of the bore-hole study with those of laboratory experiments, not only because of the difference in dimensions and properties of the ice but also because of the difference in the method of evaluation of the stress and strain-rate. However, an experimental relation obtained by Barnes and others (1971), which is for stress lower than $3 \mathrm{MN} \mathrm{m}^{-2}$ and after the temperature had been adjusted to $-35^{\circ} \mathrm{C}$, is also shown by a broken line in Figure 4 . The results of the present study show rheological properties of ice intermediate between those deduced in the laboratory and those obtained by Paterson.

\section{CONCLUDING REMARKS}

Closure rates of a $700 \mathrm{~m}$ deep bore hole were obtained at Mizuho Station. Due to a scarcity of measurements in the early stage after drilling, we could not clearly recognize the secondary (steady) creep rate. It seems, from the creep curves of closure, that transient (decelerating) creep is followed by tertiary (accelerating) creep. Hence we determined the minimum rate of strain, which should correspond to the conventional secondary creep rate. Although the estimated minimum strain-rates involve some degree of error, caused by fitting smoothed curves to data, the strain-rates correlate well with the stresses in the form of a power law in which $n=2.87$ in the depth range from 280 to $540 \mathrm{~m}$.

Closure rates at Mizuho Station are found to be much higher than those obtained from other ice sheets and ice caps (Paterson 1977). Narita and others (1986) showed that at Mizuho Station mean grain-size (area) is $8-10 \mathrm{~mm}^{2}$ in the layer from 300 to $700 \mathrm{~m}$ depth, and that the $c$-axis alignment, which is random at shallow depths, becomes a great-circle girdle at $600 \mathrm{~m}$ depth. The $c$-axis concentration (e.g. single-maximum) favors the bore-hole tilting, i.e. shear deformation, but it tends to hamper the bore-hole closure, as pointed out by Thwaites and others (1984) and Fisher and Koerner (1986).

At present we cannot account for the higher closure strain-rates in the bore hole at Mizuho Station. Extensive thinning (Naruse 1979) or the recent variation in the ice sheet (Nishio, in preparation) in Mizuho Plateau might be elucidated by this flow enhancement.

More field research on bore-hole tilt and closure is necessary, as well as laboratory studies on the dependence of ice textures, $c$-axis fabrics, and impurities upon ice deformation.

\section{ACKNOWLEDGEMENTS}

We are grateful to $\mathrm{Dr} \mathrm{H}$. Narita of the Institute of Low Temperature Science (ILTS), Dr Y. Fujii and Dr F. Nishio of the National Institute of Polar Research (NIPR), Mr M. Yoshida of the Hakusan Corporation, Dr Y. Ageta of Nagoya University, and other wintering members of JARE-25, JARE-26, and JARE-27 for their assistance with field measurements. We are also indebted to Professor A. Higashi of the International Christian University for his generous supervision of this project, and to Professor N. Maeno of ILTS for valuable comments on this paper.

\section{REFERENCES}

Barnes, P., D. Tabor, and J.C.F. Walker. 1971. The friction and creep of polycrystalline ice. Proc. $R$. Soc. London, Ser. A, 324(1557), 127-155.

Fisher, D.A., and R.M. Koerner. 1986. On the special rheological properties of ancient microparticle-laden Northern Hemisphere ice as derived from bore-hole and core measurements. J. Glaciol., 32(112), 501-510.

Gow, A.J. 1963. Results of measurements in the 309 meter bore hole at Byrd Station, Antarctica. J. Glaciol., 4(36), 771-784.

Gundestrup, N.S., and B.L. Hansen. 1984. Bore-hole survey at Dye 3, south Greenland. J. Glaciol., 30(106), 282-288.

Kawada, K., M. Yoshida, and R. Naruse. 1986. Borehole closure at Mizuho Station, Antarctica. Mem. Natl Inst. Polar Res. Special Issue, 45, 66-73.

Nakawo, M., and H. Narita. 1985. Density profile of a $413.5 \mathrm{~m}$ deep fresh core recovered at Mizuho Station, East Antarctica. Mem. Natl Inst. Polar Res. Special Issue, $39,141-156$.

Narita, H., M. Nakawo, and Y. Fujii. 1986. Textures and fabrics of 700-m deep ice core obtained at Mizuho Station, East Antarctica. Mem. Natl Inst. Polar Res. Special Issue, 45, 74-77.

Naruse, R. 1979. Thinning of the ice sheet in Mizuho Plateau, East Antarctica. J. Glaciol., 24(90), 45-52.

Naruse, R., K. Shimbori, A. Akitaya, and Y. Suzuki. 1985. A tandem diameter gauge for use in Antarctic ice hole. Mem. Natl Inst. Polar Res. Special Issue, 39, 219-222.

Nye, J.F. 1953. The flow law of ice from measurements in glacier tunnels, laboratory experiments and the Jungfraufirn borehole experiment. Proc. $R$. Soc. London, Ser. A, 219(1139), 477-489.

Okuhira, F., R. Naruse, M. Nakawo, and K. Kawada. 1987. Diameter measurements of a 700-m deep bore-hole at Mizuho Station, East Antarctica (abstract). Proc. NIPR Symp. Polar Meteorol. Glaciol., 1, 156.

Paterson, W.S.B. 1977. Secondary and tertiary creep of glacier ice as measured by borehole closure rates. Rev. Geophys. Space Phys., 15(1), 47-55.

Thwaites, R.J., C.J.L. Wilson, and A.P. McCray. 1984. Relationship between bore-hole closure and crystal fabrics in Antarctic ice core from Cape Folger. J. Glaciol., 30(105), 171-179. 